\title{
THE CONTRIBUTORS
}

william matthews, Professor of English at the University of California, Los Angeles, since 1939, has published on the history of the pronunciation of English and its dialects, on Cockney, on American history, on British and American diaries and autobiographies, and especially on late medieval literature, notably the Arthurian. He will shortly issue a new biographical study of Sir Thomas Malory and a definitive edition of Pepys's diary.

PhILlIP w. Damon, Professor of English at the University of California, Santa Barbara, is equally concerned with both Greco-Roman and medieval literature; he had previously taught English at Cornell, and Classics at Harpur College and Ohio State University. He has published a monograph with William C. Helmbold on Propertius, and the book Modes of Analogy in Ancient and Medieval Verse.

urban tigner holmes, Jr., Kenan Professor of Romance Philology at the University of North Carolina, where he has taught since 1925 , plays a preeminent role in the effort to understand medieval literature through the archaeological and numismatic, as well as the written, remains of the time that produced a particular work. His Daily Living in the Twelfth Century admirably reflects this wide view.

Stephen G. Nichols, JR., formerly Assistant Professor of French at the University of California, Los Angeles, currently in the Department of Comparative Literature, University of Wisconsin, is particularly concerned with medieval epics and histories. In $196 \mathrm{I}$ he published Formulaic Diction and Thematic Composition in the Chanson de Roland. 
